\title{
Pemberdayaan dan Peningkatan Perilaku Cuci Tangan Pakai Sabun (CTPS) Dalam Pencegahan Penyebaran Covid-19 di Kelurahan Dorpedu Kota Ternate Provinsi Maluku Utara
}

\author{
Purnama Sidebang \\ Jurusan Kesehatan Lingkungan, Poltekkes Kemenkes Ternate \\ *Corresponding Author. Email: purthebank88@gmail.com
}

\begin{abstract}
The purpose of this community service is to increase the knowledge and competence of the community, especially housewives in clean and healthy living behavior, namely about washing hands with soap, so as to prevent the transmission of the Covid-19 disease. The method used in this service is counseling and community empowerment. The procedure for implementing this activity begins with a pretest, counseling, demonstration, mentoring, distribution of pocket books and leaflets and ends with a posttest. The results of this service activity show that there is an increase in the knowledge of the Dorpedu Village community regarding the implementation of CTPS, important times for the implementation of CTPS and the community is motivated to be consistent in implementing it, besides that facilities for washing hands with soap are already available as an effort to prevent the transmission of Covid-19. Overall, the group of housewives was enthusiastic in participating in each of these service activities.
\end{abstract}

Abstrak: Tujuan kegiatan pengabdian masyarakat ini adalah untuk meningkatkan pengetahuan dan kompetensi masyarakat khususnya ibu rumah tangga dalam hal berperilaku hidup bersih dan sehat yaitu tentang cuci tangan pakai sabun, sehingga dapat mencegah penularan penyakit Covid-19. Metode yang digunakan dalam pengabdian ini adalah penyuluhan dan pemberdayaan masyarakat. Prosedur pelaksanaan kegiatan ini dimulai dengan pretest, penyuluhan, peragaan, pendampingan, pembagian buku saku dan leaflet serta diakhiri dengan posttest. Hasil kegiatan pengabdian ini menunjukkan bahwa ada peningkatan pengetahuan masyarakat Kelurahan Dorpedu dalam hal pelaksanaan CTPS, waktu-waktu penting pelaksanaan CTPS dan masyarakat termotivasi untuk konsisten dalam menerapkannya, selain itu fasilitas untuk cuci tangan dengan sabun sudah terdapat sebagai bentuk upaya pencegahan penularan Covid-19. Secara keseluruhan kelompok ibu rumah tangga antusias dalam mengikuti setiap rangkaian kegiatan pengabdian ini.
Article History:

Received: 29-08-2021

Reviewed: 17-09-2021

Accepted: 11-10-2021

Published: 13-11-2021

Key Words:

CTPS, Clean and

Healthy Living

Behavior, Covid-19.

\section{Sejarah Artikel:}

Diterima: 29-08-2021

Direview: 17-09-2021

Disetujui: 11-10-2021

Diterbitkan: 13-11-2021

\section{Kata Kunci:}

CTPS, Perilaku Hidup Bersih Dan Sehat, Covid19.

How to Cite: Sidebang, P. (2021). Pemberdayaan dan Peningkatan Perilaku Cuci Tangan Pakai Sabun (CTPS) Dalam Pencegahan Penyebaran Covid-19 di Kelurahan Dorpedu Kota Ternate Provinsi Maluku Utara. Jurnal Pengabdian UNDIKMA, 2(2), 235-242. doi:https://doi.org/10.33394/jpu.v2i2.4154

\section{Pendahuluan}

Situasi pandemi Covid-19 yang melanda dunia termasuk Indonesia pada awal tahun 2020 diiringi tren yang senantiasa meningkat menjadi masalah yang berdampak kepada masyarakat luas. Berbagai upaya dan kebijakan ditetapkan oleh pemerintah untuk mencegah penularan virus penyebab Covid-19 seperti upaya 3M yaitu memakai masker, menjaga jarak dan mencuci tangan menggunakan sabun dan air mengalir (Kemenkes RI, 2020; Mensesneg RI, 2020). 
Perilaku cuci tangan pakai sabun merupakan bagian dari program Perilaku Hidup Bersih dan Sehat (PHBS) di tingkat rumah tangga. Dengan memberdayakan anggota rumah tangga agar sadar, mau dan mampu memparaktikkan perilaku hidup bersih dan sehat diharapkan mampu menolong dirinya sendiri (mandiri) dibidang kesehatan dan berperan aktif dalam mewujudkan kesehatan masyarakat (Kementerian Kesehatan, 2011).

Mencuci tangan dengan sabun (CTPS) adalah salah satu tindakan sanitasi dengan membersihkan tangan dan jari jemari menggunakan air dan sabun oleh manusia untuk menjadi bersih dan memutuskan mata rantai kuman. Dengan penerapan CTPS maka penyebaran penyakit dapat dicegah. Hal ini dilakukan karena tangan sering kali menjadi agen yang membawa kuman dan menyebabkan patogen berpindah dari satu orang ke orang lain, baik dengan kontak langsung ataupun kontak tidak langsung. Mencuci tangan pakai sabun diketahui dapat mengurangi penularan penyakit yang berkaitan dengan pernapasan (Jefferson et al., 2009), molekul sabun akan merusak membran lipid bagian luar virus SARS-CoV-2, membunuh mikroba dan air yang mengalir kemudian akan membuang fragmen virus yang telah rusak (Unesco, 2020).

Rendahnya kebiasaan mencuci tangan pakai sabun dikalangan masyarakat merupakan faktor risiko perilaku berbagai penyakit seperti diare, gangguan pernafasan termasuk penyakit Covid-19. Data yang dihimpun dari pusat data Kementerian Kesehatan tahun 2020 menunjukkan bahwa jumlah kasus positif Covid-19 per 31 Juli 2020 sebanyak 108.376 kasus, dengan jumlah kasus aktif sebanyak 36.271 kasus, meninggal sebanyak 5.131 kasus. Jumlah kasus untuk Provinsi Maluku Utara mencapai 1.530 kasus dan meninggal dunia sebanyak 48 orang (Covid-19, 2020). Data ini menunjukkan bahwa kasus Covid-19 semakin banyak dan akan semakin tinggi jika diperkirakan dengan data kasus Covid-19 yang belum terlapor.

Mencuci tangan pakai sabun diketahui dapat menurunkan resiko kejadian penyakit diare sebesar 45\% (WHO, 2009), risiko penularan penyakit Covid-19 sebesar 35\%, disamping pemakaian masker kain yang dapat menurunkan risiko penularan sebesar $45 \%$ dan masker bedah sebesar 70\% (Covid-19, 2020). Ketersediaan sarana dan prasarana atau fasilitas kesehatan merupakan faktor pemungkin terhadap suatu perilaku baik. Penelitian menunjukkan bahwa ketersediaan sarana air bersih yang kurang akan menghambat perilaku cuci tangan pakai sabun pada masyarakat (Mustikawati, 2017; Risnawaty, 2016). Namun data Riskesdas 2018 menunjukkan bahwa proporsi pemakaian air per orang per hari di rumah tangga untuk Maluku Utara mayoritas berada dalam kategori akses menengah (pemakaian air antara 50-99,9 liter/orang/hari) yaitu sebesar 61,2\% (Kementerian Kesehatan, 2019) sehingga ketersediaan air bukanlah menjadi masalah rendahnya perilaku cuci tangan pakai sabun di kalangan masayarakat. Selain itu, Kota Ternate memiliki potensi sumber air yang melimpah, terletak dipesisir pantai yang dikelilingi oleh lautan perairan seluas $5.547,55 \mathrm{~km}^{2}$ (BPS Kota Ternate, 2018).

Kurangnya pengetahuan akan waktu-waktu cuci tangan pakai sabun, cara cuci tangan pakai sabun yang baik menyebabkan masyarakat belum menjalankan perilaku cuci tangan yang benar (Mustikawati, 2017). Perilaku cuci tangan yang tidak baik masih tinggi pada masyarakat khususnya kelompok perempuan (Risnawaty, 2016). Data Riskesdas tahun 2018 menunjukkan bahwa proporsi masyarakat di Indonesia yang berperilaku cuci tangan dengan benar pada penduduk umur $\geq 10$ tahun hanya 49,8\% dan untuk provinsi Maluku Utara memiliki proporsi yang lebih rendah dari proporsi nasional yaitu 31,8\%, menempati posisi keempat terendah di Indonesia setelah provinsi Nusa Tenggara Timur, Papua dan Aceh (Kementerian Kesehatan, 2019). Mayoritas ibu rumah tangga di Ternate memiliki perilaku cuci tangan yang tidak baik, sementara persentase kepemilikan sarana air bersih sudah baik 
(Kompani, 2018). Perilaku cuci tangan tidak baik ini meliputi cara cuci tangan yang belum sesuai dengan cara cuci tangan yang baik dan benar, sering kali hanya menggunakan air saja tanpa menggunakan sabun serta minimnya pemahaman tentang waktu kritis kapan harus mencuci tangan.

Rendahnya proporsi masyarakat yang berperilaku cuci tangan dengan baik ini melatarbelakangi dilakukannya pengabdian masyarakat dengan sasaran para ibu rumah tangga ditengah kondisi pandemi Covid-19. Adapun tujuan kegiatan pengabdian masyarakat ini adalah untuk meningkatkan pengetahuan dan kompetensi masyarakat terutama ibu rumah tangga dalam hal berperilaku hidup bersih dan sehat terutama perilaku cuci tangan pakai sabun, sehingga dapat mencegah penularan penyakit Covid-19.

\section{Metode Pengabdian}

Metode pengabdian yang akan dilakukan dalam kegiatan ini adalah pemberdayaan masyarakat yang diawali dengan penyuluhan tentang perilaku hidup bersih dan sehat dalam hal cuci tangan pakai sabun sebagai upaya pencegahan penularan penyakit Covid-19 dan dilanjutkan dengan pemberdayaan masyarakat dalam peningkatan pemahaman dan motivasi pengadaan fasilitas cuci tangan dengan air mengalir menggunakan ember bertutup dirumah masing-masing. Pengabdian masyarakat ini dilakukan di Kelurahan Dorpedu Kecamatan Pulau Ternate, Kota Ternate Provinsi Maluku Utara. Pengabdian dilakukan kepada masyarakat RT 02 bekerja sama dengan aparat pemerintah kelurahan yaitu ketua RT 02 . Tahap persiapan, pelaksanaan hingga evaluasi pada bulan November - Desember 2020. Khalayak sasaran dalam kegiatan ini adalah masyarakat di kelurahan Dorpedu, khususnya kelompok ibu rumah tangga.

Pemberdayaan masyarakat ini menggunakan metode penyuluhan, berikut tahap kegiatan pengabdian masyarakat yang dilakukan:

\section{1) Tahap Persiapan}

Pada tahap ini, tim pelaksana pengabdian masyarakat melakukan analisis permasalahan dan kebutuhan masyarakat Kelurahan Dorpedu sehubungan dengan kondisi pandemi Covid-19 menyusunnya dalam bentuk proposal pelaksanaan pengabdian masyarakat, kemudian tim melakukan penjajakan dan koordinasi dengan aparat pemerintah dalam hal ini kantor kelurahan Dorpedu untuk mendapatkan perizinan pelaksanaan kegiatan. Tahap persiapan berikutnya adalah melakukan survei lokasi dan penentuan lokasi pelaksanaan kegiatan, tepatnya di rumah ketua RT 02. Tim pelaksana pengabdian selanjutnya mempersiapkan materi sosialisasi, kebutuhan alat dan bahan yang diperlukan dalam pelaksanaan pengabdian.

2) Tahap Pelaksanaan

Tahap pelaksanaan pengabdian masyarakat ini meliputi pre-test, penyuluhan, pemberdayaan ibu rumah tangga sebagai role model pelaksanaan perilaku CTPS.

a) Pre test

Pada tahap pre-test dilakukan pengukuran pengetahuan dan cara mencuci tangan pakai sabun dengan benar pada ibu rumah tangga sebagai upaya pemutusan penularan penyakit Covid-19. Pengukuran pengetahuan dilakukan dengan menggunakan instrumen kuesioner yang dijawab oleh masyarakat yang hadir.

b) Penyuluhan

Pada tahap penyuluhan, tim pelaksana pengabdian masyarakat melakukan penyuluhan kepada sasaran. Masyarakat diberikan praktek percontohan cara cuci tangan pakai sabun yang baik dan benar sesuai dengan 6 langkah yang direkomendasikan oleh WHO. Pada 
tahap ini sasaran dari kegiatan pengabdian masyarakat diberikan flyer dan buku saku tentang perilaku cuci tangan pakai sabun dengan cara yang benar dan pada waktu-waktu yang tepat sebagai upaya pemutusan penularan penyakit Covid-19. Selain itu, sosialisasi juga dilakukan dengan menggunakan banner cetak berisi tentang langkah-langkah CTPS yang baik dan benar, banner kemudian diserahkan kepada aparat kelurahan untuk kemudian diletakkan di kantor kelurahan.

c) Peragaan pelaksanaan CTPS

Setelah pemberian materi melalui penyuluhan, tim pelaksana pengabdian memperagakan cara cuci tangan pakai sabun yang baik dan benar.

d) Pemberdayaan ibu rumah tangga sebagai role model pelaksanaan perilaku cuci tangan pakai sabun ditengah keluarga.

Pada tahap ini tim pengabdian masyarakat mendampingi para ibu rumah tangga untuk mempraktekkan cuci tangan pakai sabun dengan benar dan memotivasi ibu rumah tangga untuk memanfaatkan ember/jeregen yang tersedia dirumah masing-masing untuk dibuat menjadi fasilitas cuci tangan sederhana atau mengadakan sarana cuci tangan dan penyediaan sabun cuci tangan dirumah masing-masing. Pada tahap ini, sasaran kegiatan pengabdian masyarakat diberikan praktek cuci tangan dengan benar sesuai anjuran WHO oleh tim pelaksana pengabdian.

3) Evaluasi

Evaluasi hasil pelaksanaan kegiatan ini dilakukan sebanyak 2 kali, yaitu pada tanggal 25 November 2020 dan tanggal 1 Desember 2020, bertempat di Kelurahan Dorpedu Rt02. Evaluasi yang dilakukan meliputi evaluasi peningkatan pengetahuan masyarakat tentang CTPS yang baik dan benar melalui post test menggunakan kuesioner yang sama saat pelaksanaan pre-test. Hasil pre-test dan post test kemudian dianalisis secara deskriptif sehingga diperoleh nilai perubahan skor pengetahuan sebelum dan setelah penyuluhan yang disajikan dalam bentuk grafik. Selain itu dilakukan evaluasi pelaksanaan cara cuci tangan pakai sabun dengan 6 langkah yang dilakukan oleh masyarakat, evaluasi dilakukan dengan mengamati ibu rumah tangga yang sedang memperagakan cuci tangan kemudian membandingkannya dengan langkah-langkah cuci tangan yang baik dan benar seperti yang disampaikan saat penyuluhan, serta evaluasi ketersediaan fasilitas cuci tangan di rumah peserta penyuluhan dilakukan dengan melakukan kunjungan ke rumah peserta penyuluhan minggu berikutnya.

\section{Hasil Pengabdian dan Pembahasan}

Pelaksanaan pengabdian kepada masyarakat ini dimulai dengan pelaksanaan pretest untuk mengukur pengetahuan masyarakat tentang perilaku cuci tangan pakai sabun yang benar pada waktu yang tepat dengan cara yang benar, kemudian kegiatan dilanjutkan dengan penyuluhan tentang penyakit Covid-19 dan cara cuci tangan yang baik dan benar, pada saat penyuluhan terlihat bahwa masyarakat antusias dalam mengikutinya beberapa pertanyaan diajukan oleh masyarakat selama kegiatan penyuluhan. Materi penyuluhan yang diberikan meliputi pengertian Perilaku Hidup bersih dan Sehat (PHBS) serta contoh-contohnya, pengertian CTPS serta enam langkah CTPS yang benar sesuai dengan anjuran WHO, waktuwaktu kritis harus melakukan CTPS serta penyuluhan tentang Covid-19 dan cara pencegahan penularannya.

Kegiatan dilanjutkan dengan peragaan cara CTPS 6 langkah yang benar oleh mahasiswa anggota tim pengabdi, dilanjutkan dengan pemberdayaan dan pendampingan masyarakat dalam melaksanakan CTPS, pada saat ini masyarakat langsung didampingi dan 
dibimbing untuk melakukan cara CTPS yang benar, selanjutnya diadakan pembagian leaflet dan buku saku yang berisi tentang materi langkah CTPS yang benar sebagai upaya pencegahan Covid-19. Pengabdian diakhiri dengan sesi foto dan pembagian sabun cuci tangan dan masker sebagai bentuk dukungan tim pelaksana dalam upaya mendorong masyarakat untuk mencegah penyebaran Covid-19.

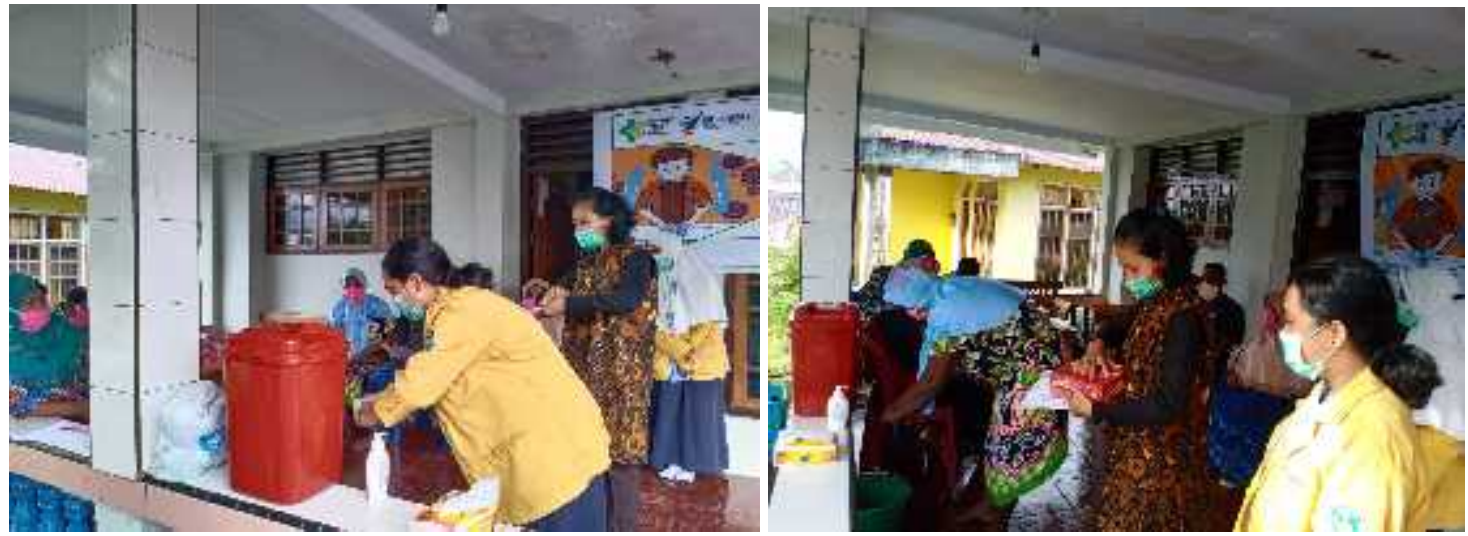

Gambar 1. Pelaksanaan Sosialisasi dan Pemberdayaan Masyarakat Melaksanakan CTPS 6 Langkah Didampingi Tim Pengabdi

Pelaksanaan posttest dilakukan sebagai bentuk evaluasi pelaksanaan pengabdian masyarakat, hasil evaluasi menunjukkan adanya peningkatan pengetahuan masyarakat tentang langkah-langkah CTPS yang benar. WHO menyatakan 6 langkah CTPS meliputi 1) menggosok secara bersamaan telapak tangan yang telah dibasahi dan diberi sabun, 2) menggosok punggung kedua tangan secara bersamaan, 3) menjalin kedua telapak tangan lalu digosok-gosokkan, 4) menautkan jari-jari antara kedua telapak tangan secara berlawanan, 5) menggosok ibu jari secara memutar dilanjutkan dengan daerah antara jari telunjuk dan ibu jari secara bergantian dan 6) menggosok ujung jari pada telapak tangan kemudian pergelangan tangan secara memutar kemudian dibilas dan dikeringkan.

Setelah diberikan penyuluhan dan pendampingan cara CTPS yang benar, masyarakat semakin memahami waktu-waktu kritis pelaksanaan CTPS seperti setelah batuk atau bersin, ketika merawat orang yang sedang sakit, sebelum dan sesudah mengolah makanan, sebelum dan sesudah makan, sebelum menyusui, setelah ke toilet, sebelum menyentuh mata, mulut dan hidung, setelah menyentuh benda-benda yang diduga terkontaminasi virus, atau setiap kali tangan kotor maka wajib melakukan cuci tangan mengguankan sabun dan air mengalir. Dengan melakukan CTPS secara benar dan tepat maka penularan penyakit yang ditularkan melalui tangan seperti diare, kolera, disentri, typhus, kecacingan penyakit kulit, ISPA termasuk Covid-19 diharapkan dapat diminimalisir. Peningkatan pengetahuan masyarakat setelah diberikan penyuluhan dan pendampingan terlihat dari hasil evaluasi posttest (grafik 1). Selain adanya peningkatan pengetahuan, masyarakat juga semakin termotivasi untuk melakukan CTPS yang benar dalam kehidupan sehari-hari. Evaluasi kedua menunjukkan bahwa masyarakat telah memiliki fasilitas cuci tangan dengan kelengkapan sabun dan ember cuci tangan.

Setelah pelaksanaan kegiatan pengabdian masyarakat ini, diperoleh komitmen dari pihak pemerintahan dalam hal ini bapak Ketua RT bahwa upaya untuk senantiasa mengingatkan masyarakat dalam berperilaku hidup bersih dan sehat khususnya pelaksanaan CTPS dengan benar akan dilakukan, melalui pengumuman melalui mesjid maupun sosialisasi langsung ke warga lainnya. Pentingnya dukungan dari pemerintah dan masyarakat setempat 
sangat penting untuk keberlanjutan suatu program. Seperti pengabdian yang dilakuan oleh Rahman dkk terkait implementasi Gerakan Mayarakat Hidup Sehat (Germas) mendapatkan dukungan dari pemerintah dan masyarakat setempat, sehingga kegiatan itu dapat berlanjut (Rahman, Suhaeb, \& Najamuddin, 2021).

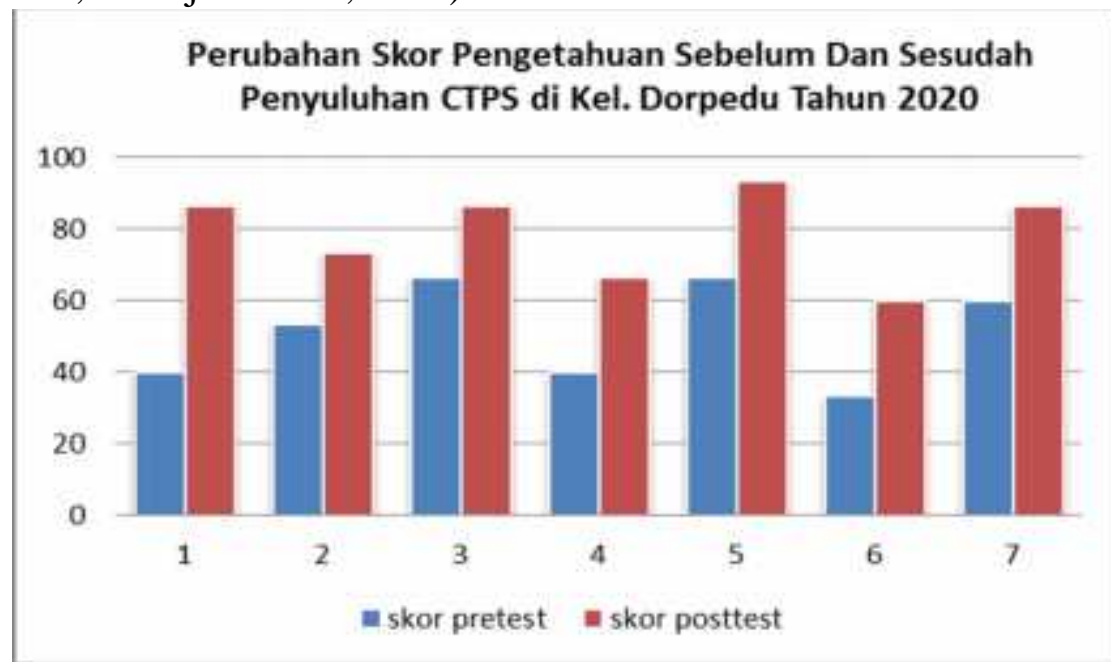

\section{Grafik 1. Analisa Hasil Pretest dan Posttest yang Menunjukkan Perubahan Skor Pengetahuan Sebelum dan Sesudah Penyuluhan CTPS}

Sosialisasi perilaku CTPS juga dilakukan oleh Sinaga dan tim di Kabupaten Nias Utara, hasil menunjukkan bahwa masyarakat yang tidak mengetahui langkah CTPS yang benar dan waktu-waktu CTPS yang tepat menjadi termotivasi untuk melakukan CTPS sebelum dan sesudah beraktivitas (Sinaga, Munthe, \& Bangun, 2020).

Perilaku cuci tangan pakai sabun merupakan bagian dari program Perilaku Hidup Bersih dan Sehat (PHBS) di tingkat rumah tangga. Dengan memberdayakan anggota rumah tangga agar sadar, mau dan mampu memparaktikkan perilaku hidup bersih dan sehat diharapkan mampu menolong dirinya sendiri (mandiri) dibidang kesehatan dan berperan aktif dalam mewujudkan kesehatan masyarakat (Kementerian Kesehatan, 2011).

Pencapaian program PHBS ditingkat rumah tangga dengan praktik CTPS yang baik dan benar tentu harus didukung dengan ketersediaan fasilitas cuci tangan seperti ember, sabun dan tentunya air yang mengalir dengan cukup. Seperti halnya pengabdian masyarakat yang dilakukan oleh Risfianty dan tim yaitu pemberdayaan kesehatan masyarakat melalui pengadaan fasilitas cuci tangan di masa pandemi Covid-19 di masjid dan mushala Dusun Montong Are tengah (Risfianty \& Indrawati, 2020). Pengadaan fasilitas cuci tangan di masa pandemi Covid-19 ini sangat penting, baik di tempat-tempat umum maupun di skala rumah tangga oleh akrena itu, dalam pelaksanaan pengabdian ini, pemberian fasilitas berupa sabun cuci tangan dan evaluasi keberadaan fasilitas cuci tangan juga penting untuk dilakukan.

Mencuci tangan dengan sabun adalah salah satu tindakan sanitasi dengan membersihkan tangan dan jari jemari menggunakan air dan sabun oleh manusia untuk menjadi bersih dan memutuskan mata rantai kuman. Mencuci tangan dengan sabun (CTPS) dikenal juga sebagai salah satu upaya pencegahan penyakit. Hal ini dilakukan karena tangan sering kali menjadi agen yang membawa kuman dan menyebabkan patogen berpindah dari satu orang ke orang lain, baik dengan kontak langsung ataupun kontak tidak langsung. Mencuci tangan pakai sabun diketahui dapat mengurangi penularan penyakit yang berkaitan dengan pernapasan (Jefferson et al., 2009), molekul sabun akan merusak membran lipid 
bagian luar virus SARS-CoV-2, membunuh mikroba dan air yang mengalir kemudian akan membuang fragmen virus yang telah rusak (Unesco, 2020).

\section{Kesimpulan}

Hasil kegiatan pengabdian ini menunjukkan bahwa ibu rumah tangga telah memiliki peningkatan pengetahuan dalam hal berperilaku hidup bersih dan sehat terutama perilaku cuci tangan pakai sabun dengan benar serta mengetahui waktu - waktu kritis harus cuci tangan, selain itu hasil evaluasi menunjukkan bahwa masyarakat telah mampu melaksanakan CTPS dengan langkah yang benar dengan demikian diharapakan penularan penyakit Covid19 dapat dicegah.

\section{Saran}

Adapaun saran yang dapat disampaikan berdasarkan hasil kegiatan ini adalah bagi Ibu rumah tangga diharapkan agar konsisten dalam menyediakan sarana cuci tangan (ember, sabun dan lap) serta tetap melakukan CTPS dengan langkah yang benar, pada waktu-waktu yang tepat sebagai bentuk upaya pencegahan penyebaran berbagai penyakit termasuk Covid-19. Pelaksanaan kegiatan yang dilakukan di siang hari menjadi salah satu hambatan dalam pelaksanaankegiatan ini, karena pada saat siang hari masyarakat beraktivitas di kebun sehingga jumlah masyarakat yang mengikuti kegiatan tidak sebanyak yang telah diundang. Selain itu disarankan juga kepada dinas Kesehatan dan Dinas Pendidikan agar senantiasa melakukan follow up dengan rutin melakukan kunjungan kerja di Kelurahan Dorpedu untuk senantiasa mengajak masyarakat melakukan CTPS dengan langkah yang benar baik dilingkungan masyarakat dan sekolah.

\section{Daftar Pustaka}

BPS Kota Ternate. (2018). Kota Ternate Dalam Angka 2018. Kota Ternate. Retrieved from https://ternatekota.bps.go.id/publication/2018/08/16/380c397a43f56eb87bdc0f5d/kota -ternate-dalam-angka-2018.html

Covid-19, S. P. (2020). Peta Sebaran Kasus Per Provinsi. Retrieved July 31, 2020, from https://covid19.go.id/peta-sebaran

Jefferson, T., Mar, C. Del, Dooley, L., Ferroni, E., Al-Ansary, L. A., Foxlee, R., \& Rivetti, A. (2009). Physical Interventions to Interrupt or Reduce the Spread of Respiratory Viruses: $\quad$ systematic review. Bmj, 339:b3675, 1-10. https://doi.org/10.1136/bmj.b3675

Kemenkes RI. (2020). Keputusan Menteri Kesehatan Republik Indonesia Nomor HK.01.07/MENKES/382/2020 Tentang Protokol Kesehatan Bagi Masyarakat Di Tempat dan Fasilitas Umum Dalam Rangka Pencegahan dan Pengendalian Corona Virus Disease 2019 (COVID-19). Jakarta: Biro Hukum dan Organisasi Sekretariat Jenderal Kementerian Kesehatan. Retrieved from https://covid19.go.id/storage/app/media/Regulasi/2020/Juni/KMK No. HK.01.07MENKES-382-2020 ttg Protokol Kesehatan Bagi Masyarakat di Tempat dan Fasilitas Umum Dalam Rangka Pencegahan COVID-19.pdf

Kementerian Kesehatan. (2011). Peraturan Menteri Kesehatan Republik Indonesia Nomor: 2269/Menkes/Per/XI/2011. Jakarta: Kementerian Kesehatan. Retrieved from http://promkes.kemkes.go.id/download/jsg/files13583Pedoman_umum_PHBS.pdf

Kementerian Kesehatan. (2019). Laporan Nasional Riskesdas 2018. Jakarta: Badan penelitan dan Pengembangan Kesehatan. Retrieved from 
http://labmandat.litbang.depkes.go.id/images/download/laporan/RKD/2018/Laporan_ Nasional_RKD2018_FINAL.pdf

Kompani, T. A. (2018). Gambaran Sanitasi Dasar dan Personal Hygiene Ibu dengan Kejadian Diare pada Balita di Wilayah Kerja Puskesmas Siko Kota Ternate Provinsi Maluku Utara Tahun 2018. Politeknik Kesehatan Kemenkes Ternate.

Mensesneg RI. (2020). Instruksi Presiden Republik Indonesia Nomor 6 Tahun 2020 tentang Peningkatan Disiplin dan Penegakan Hukum Protokol Kesehatan Dalam Pencegahan dan Pengendalian Corona Virus Disease 2019. Jakarta. Retrieved from https://corona.minahasa.go.id/wp-content/uploads/2020/08/Inpres-Nomor-6-Tahun2020-1.pdf

Mustikawati, I. S. (2017). Perilaku Cuci Tangan Pakai Sabun Studi Kualitatif pada Ibu-Ibu di Kampung Nelayan Muara Angke Jakarta Utara. Arkesmas, 2(1), 115-125.

Rahman, A., Suhaeb, F. w., \& Najamuddin. (2021). Sosialisasi Gerakan Masyarakat Hidup Sehat di Desa Bulutellue Kabupaten Sinjai Provinsi Sulawesi Selatan. Jurnal Pengabdian UNDIKMA, 2(1), 9-17. https://doi.org/https://doi.org/10.33394/jpu.v2i1.3728

Risfianty, D. K., \& Indrawati. (2020). Pemberdayaan Kesehatan Masyarakat Melalui Pengadaan Fasilitas Cuci Tangan pada Masa Pandemi Covid-19 di Masjid dan Mushala Dusun Montong Are Tengah. Jurnal Pengabdian UNDIKMA, 1(2), 94-99. https://doi.org/https://doi.org/10.33394/jpu.v1i2.2724

Risnawaty, G. (2016). Faktor Determinan Perilaku Cuci Tangan Pakai Sabun (CTPS) pada Masyarakat di Tanah Kalikedinding. Jurnal Promkes, 4(1), 70-81.

Sinaga, L. R. V., Munthe, S. A., \& Bangun, H. A. (2020). Sosialisai Perilaku Cuci Tangan Pakai Sabun Di Desa Sawo Sebagai Bentuk Kepedulian Terhadap Masyarakat Ditengah Mewabahnya Virus COVID-19. Jurnal Abdimas Mutiara, 1(September), $19-28$.

Unesco. (2020). How Soap Kills Covid-19 on Hands. Retrieved July 31, 2020, from https://en.unesco.org/news/how-soap-kills-covid-19-hands

WHO. (2009). WHO Guidelines on Hand Hygiene in Health Care : a Summary First Global Patient Safety Challenge Clean Care is Safer Care. Geneva: World Health Organization. Retrieved from https://www.who.int/gpsc/5may/tools/who_guidelineshandhygiene_summary.pdf 